\title{
METAMORFOZA STOSUNKU DO MĘŻCZYZN Apulejusz o mężczyznach odpowiedzialnych za patologiczne sytuacje w rodzinie
}

Metamorfozy Apulejusza z Madaury są utworem wielowarstwowym, w którym można znaleźć argumenty nieomal na każde, zaproponowane przez historyka, w ramach wiedzy o epoce, interpretacje jego poglądów ${ }^{1}$. Odnosi się to także do problematyki małżeńsko-rodzinnej². Pozornie odpowiedzialną za niepowodzenia życia małżeńskiego i rodzinnego jest u niego przede wszystkim kobieta. Takie stanowisko ma swoją długą tradycję w filozofii i moralistyce greckiej i nieco słabiej - rzymskiej. Wystarczy przypomnieć tyrady przeciwko kobietom wygłaszane przez satyryków Marcjalisa i Juwenalisa, oskarżenia biografów cesarzy o demoniczny wpływ kobiet na nich, ale i niektórych moralistów oraz filozofów, a później niektórych Ojców Kościoła ${ }^{3}$. Ja jednak rozważę wariant interpretacyjny, który tę odpowiedzialność kieruje

* Prof. dr hab. Juliusz Jundziłł - profesor zwyczajny na Wydziale Zamiejscowym w Bydgoszczy Wyższej Szkoły Informatyki i Umiejętności w Łodzi; e-mail: juliusz_jundzill@bydgoszcz. wsinf.edu.pl.

${ }^{1}$ Powieść antyczna, zwłaszcza rzymska (w tym na temat Metamorfoz) np.: Oxford Readings in the Roman Novel, ed. S.J. Harrison, Oxford 1999; Oxford Readings in the Greek Novel, ed. S. Swain, Oxford 1999; The Novel in the Ancient World, ed. G. Schmeling, Boston - Leiden 2003; L. Graverini - W. Keuleni - A. Barchiesi, Il romanzo antico. Forme, testi, problemi, Roma 2006; The Greek and Roman Novel, ed. T. Whitmarsh, Cambridge 2008, ale literatura naukowa na ten temat jest niezwykle bogata, łącznie z wyspecjalizowanymi periodykami poświęconymi powieści antycznej „Groningen Colloquia on the Novel” 1988- i „Ancient Narrative” 2000/2001-.

${ }^{2}$ Wprowadzenie w problematykę rodzinną u Apulejusza: J. Jundziłł, Rodzina rzymska w czasach prosperity i przemian ideowych II wieku. Apulejusz, Fronton, Marek Aureliusz i Tertulian, Bydgoszcz 1996.

${ }^{3}$ Literatura dotycząca kobiet rzymskich jest ogromna, por. ostatnio np. E. D’Ambra, Roman Women, Cambridge 2007, natomiast - o ile się orientuję - brak opracowań wyłącznie poświęconych kobietom w Metamorfozach, choć mamy np. dobry wizerunek żony Apulejusza, Pudentilli, por. E. Fantham, Aemilia Pudentilla: or the wealthy widow's choise, w: Women in Antiquity. New assessments, ed. R. Hawley - B. Levick, London - New York 1995, 220-232. Materiał dla porównań między wątkami kobiecymi w powieści Apulejusza a powieściami greckojęzycznymi czasów rzymskich jest w pracy K. Haynes, Fashioning the Femine in the Greek Novel, London - New York 2003. Stosunek Ojców Kościoła do kobiet: np. P. Brown, Ciało i społeczeństwo. Mężczyźni, kobiety i abstynencja seksualna we wczesnym chrześcijaństwie, tłum. I. Kania, Kraków 2006; ostatnio: J. Dybała, Ideat kobiety w pismach kapadockich Ojców Kościoła i Jana Chryzostoma, Łódź 2012 i podana 
na mężczyzn. Istotną sprawą będzie także możliwość porównania stanowiska Apulejusza z poglądami Ojców Kościoła w zakresie odpowiedzialności mężczyzn za prawidłowe stosunki w rodzinie, tym ważniejsze, że zalicza się go do pierwszych niechrześcijańskich świadków funkcjonowania chrześcijan w społeczeństwie rzymskim ${ }^{4}$.

Oryginalności powieści Apulejusza, a więc i jego poglądów omawianych w niniejszym artykule, nie trzeba obecnie bronić czy szerzej uświadamiać. Do przeszłości należy podkreślanie jej wtórności w stosunku do Lukiana lub domniemanego Lukiosa z Patrai ${ }^{5}$. Uważam, że jednym z argumentów na samodzielność tego utworu w stosunku do poprzedników jest dosyć przejrzyste nawiązywanie do wątków autobiograficznych, zwłaszcza przeżyć związanych z początkami małżeństwa z Pudentillą i procesem, w którym został oskarżony o uprawianie magii ${ }^{6}$. Tym samym uważam, że Metamorfozy powstały w pewnym, nie najkrótszym, okresie po procesie oraz dobrze wyrażają jego zapatrywania na życie rodzinne, tym samym nie powiela on treści pierwowzorów, bo takich tam nie było ${ }^{7}$.

Metamorfozy składają się z szeregu na pozór słabo powiązanych ze sobą noweli - historii będących pozornie przypadkowymi obrazkami z życia. Autor mniej lub bardziej niedwuznacznie sugeruje jednak specyficzną, na ogół neoplatońską, optykę postrzegania owej rzeczywistości. Być może, aby bardziej zachęcić do lektury także przeciętnego czytelnika, rozpoczyna narrację w typowo baśniowy sposób, poprzez wprowadzenie do akcji wiedźm, magii, a kończy niby realistycznym opisem nawrócenia głównego bohatera, $\mathrm{w}$ tym momencie traktowanego pozornie jako alter ego pisarza ${ }^{8}$. W takiej konwencji

tam literatura przedmiotu. W epoce Apulejusza wrogiem kobiet był Tertulian, por. Jundziłł, Rodzina rzymska w czasach prosperity, s. 65-67 i 199-212.

${ }^{4}$ Czynię to częściowo w mojej pracy Rodzina rzymska $w$ czasach prosperity, s. 140-152 i 199-212, w odniesieniu do Tertuliana. Temu problemowi zostanie także poświęcone odrębne opracowanie.

${ }^{5}$ Utwór Lukiana (Asinus) daje zarys przygód młodzieńca zamienionego w osła, ale autora nie interesują konteksty społeczno-obyczajowe, na które taki nacisk kładzie Apulejusz. Przegląd zapatrywań na poprzedników powieści Apulejusza: H.J. Mason, Greek and Latin Versions of the Ass Story, w: Aufstieg und Niedergang der römischen Welt, Teil II, Band 34.2, Berlin - New York 1994, 1665-1707 (spec. s. 1669-1691).

${ }^{6}$ Wątki autobiograficzne u Apulejusza i w literaturze antycznej: L'invention de l'autobiographie d'Hésiode à saint Augustin, Paris 1993; Jundziłl, Rodzina rzymska w czasach prosperity, s. 34-42 i 74-81; S.J. Harrison, Apuleius. A Latin Sophist, Oxford 2000, 7-8 i podana tam literatura. Magia: S. Frangoulidis, Witches, Isis and Narrative: Approaches to Magic in Apuleius' Metamorphoses, Berlin - New York 2008. Kuriozalne stanowisko T. Sapoty (Magia i religia w twórczości Apulejusza $z$ Madaury, Kraków 2001) jakoby proces i mowa były wymyślone przez Apulejusza przewijało się czasami w nauce, ale zostało dawno porzucone.

${ }^{7}$ Por. Jundziłł, Rodzina rzymska w czasach prosperity, s. 54-61. Powieść Apulejusza natomiast dobrze wpisuje się w rozwijający się w II w. nurt drugiej sofistyki; zob. odnośnie do paidei: The World of the Second Sophistic, ed. B.E. Borg, Berlin - New York 2004.

${ }^{8}$ Wprowadzenie w charakterystykę Metamorfoz np. N. Shumate, Crisis an Conversion in Apu- 
należy postrzegać także patologiczne sytuacje rodzinne, którym - przy powierzchownym odbiorze fabuły - winne są kobiety lub przypadkowy zbieg zdarzeń. W głębszej warstwie przekazu silne tropy kieruje Apulejusz w stronę odpowiedzialności mężczyzn.

Omówię w tym artykule tylko nowele tworzące całości w ramach powieści, pozostawiając do omówienia w innym miejscu pojedyncze wypowiedzi i sytuacje oderwane od takich zwartych opowieści. Analizowana będzie warstwa odniesień do świata rzeczywistego, w tym przypadku do życia małżeńsko-rodzinnego i przypuszczalne stanowisko Apulejusza w tych kwestiach.

Każda nowela i Metamorfozy jako całość mają też warstwę zabawy w aluzje literackie, nadawanie znanym motywom innych, często humorystycznych, znaczeń. Na koniec zaś Madaureńczyk przeprowadza w powieści ukrytą akcję propagandową na rzecz neoplatonizmu i umieszcza zakamuflowane rozważania na temat religii i religijności swoich czasów. Realia jednak są tak skonstruowane, że można je analizować prawie wyłącznie na ich poziomie, niekoniecznie wchodząc $\mathrm{w}$ pozostałe uwarunkowania, mogące zaciemnić wnioskowanie 9 .

Zakładam, iż Apulejusz nie pisał - na poziomie odnoszącym się do opisu warunków życia w swoich czasach - historii fantastycznych, czego dowodem jest choćby w pełni realny opis zachowań Wenus (przecież bogini) jako zazdrosnej matki i innych bohaterów fikcyjnych historii, w tym przygód głównego bohatera powieści - Lucjusza zamienionego w osła.

Historia zarządcy majątku ziemskiego (villicus $)^{10}$, który jest niewolnikiem, dotyczy w zasadzie niższych warstw społecznych, ale nie do końca. Wiedzie on, mimo swego stanu, jak można się domyślić, dostatni żywot, prowadzi m.in. rachunkowość majątku, a zatem zdobył wykształcenie, a właściciel pozostawia mu dużo swobody $\mathrm{w}$ tym, co robi ${ }^{11}$. Niewolnik pragnie jednak przyśpieszyć awans społeczny lub go dopełnić i wdaje się w romans z wolną

leius' Metamorphoses, An Arbor 1996 (wątki autobiograficzne, s. 201-249); E.D. Finkelpearl, Metamorphosis of Language in Apuleius. A Study of Allusion in the Novel, An Arbor 1998; A. Wlosok, On the Unity of Apuleius' Metamorphoses, w: Oxford Readings in the Roman Novel, s. 142-156; S.J. Harrison, Apuleius' Metamorphoses, w: The Novel in the Ancient World, s. 491-516; N. Holzberg, Powieść antyczna. Wprowadzenie, tłum. M. Wójcik, Kraków 2003, 111-120; L. Graverini, Le Metamorfosi di Apuleio: letteratura e identità, Pisa 2007. Filozoficzne zapatrywania Apulejusza: Apulejusz z Madaury, O bogu Sokratesa i inne pisma, thum. K. Pawłowski, Warszawa 2002; K. Pawłowski, Filozofia Apulejusza Platończyka z Madaury, Warszawa 1992; G. Sandy, The Greek World of Apuleius. Apuleius and the Second Sophistic, Leiden - New York - Köln 1997, ogólnie w powieści antycznej: Philosophical Presences in the Ancient Novel, ed. J.R. Morgan - M. Jones, Groningen 2007.

${ }^{9}$ Niektóre z tych realiów, ale nie odnoszące się do rodziny, omawia F. Millar (The World of the Golden Ass, w: Oxford Readings in the Roman Novel, s. 247-268).

${ }^{10}$ Por. np. J. Carlsen, Vilici and Roman Estate Managers until AD 284, Rome 1995; L. Schumacher, Niewolnictwo antyczne, thum. B. Mrozewicz, Poznań 2005, 94, 97, 165 i 233-263; Roman Slavery and Roman Material Culture, ed. M. George, Toronto 2013.

${ }^{11}$ Por. Apuleius, Metamorphoses VIII 22. 
kobietą, która być może w zamian za dostatek materialny zapewni mu dostęp do warstw średnich.

Niewolna ,żona” reaguje na taką sytuację gwałtownie, niszcząc dokumentację majątku i paląc przy tym magazyn, być może z bardziej wartościowymi plonami lub innymi cennymi dobrami, a następnie popełnia samobójstwo, topiąc się $\mathrm{w}$ studni $\mathrm{z}$ ich małym dzieckiem (synkiem? - infantulumque). Właściciel karze niewolnika okrutnie, przywiązanego do starego figowca poleca nasmarować miodem, aby mrówki ogryzły go z ciała do kości ${ }^{12}$.

Wbrew pozorom reakcja zawiedzionej towarzyszki życia zarządcy jest racjonalna: odtrącona nie ma wraz z dzieckiem szans na wyzwolenie, w dodatku może zostać z nim rozdzielona i sprzedana, aby nie przypominać nowej żonie o poprzednim stanie męża. Dziecko zamiast stać się wolnym i w miarę zamożnym (o ile to syn) następcą ojca, może trafić nawet do domu publicznego ${ }^{13}$. „Ratuje” więc siebie i dziecko od losu gorszego niż śmierć, ale i mści się skutecznie na „mężu”, niszcząc wyniki jego pracy, tym samym powodując znaczne straty w majątku jego pana.

Kara symbolicznie wskazuje na powód tragedii: żądza niewolnika (miód, figowiec) niszczy owoce ciężkiej, wspólnej pracy całej społeczności (mrówki), która pracuje w majątku, ale też jest z nim poprzez sąsiedztwo związana. Zarządca naruszył ład społeczny, przekroczył granicę między warstwami społecznymi. Właściciel jest $\mathrm{w}$ takim ujęciu lokalnym stróżem porządku społecznego, gwarantem stabilizacji. Jak na inwencję Apulejusza jest to jednak prosta i jednoznaczna fabuła, wskazująca w sposób oczywisty na winę mężczyzny, który zasłużył na tak okrutną karę nie dlatego, że był niewolnikiem, ale że spowodował nieład w lokalnym środowisku. W dodatku sprzeniewierzył się ideałowi zarządcy, przedstawionemu na przykład przez Katona i Kolumellę, jako pracowitemu i wiernemu właścicielowi, który powierza mu odpowiedzialne zadania twórczego kierowania pracami w majątku i pilnowania ładu

${ }^{12} \mathrm{Na}$ określenie związku zarządcy Apulejusz używa terminów typowych dla ludzi wolnych: obok conserva również coniuga, uxor, maritus, por. S. Treggiari, Roman Mariage, Oxford 1991, 5-11 i passim; K.K. Hersch, The Roman Wedding. Ritual and Meaning in Antiquity, Cambridge 2010, 29-33. E. Jędrkiewicz (Apulejusz, Metamorfozy albo złoty osioł, Warszawa 1976, 172) tłumaczy opis kary bardziej obrazowo: „obżarły z niego mięso i wnętrzności i obłupiły wszystkie członki, tak że same kości odarte z mięsa i łyskające okropną białością tkwiły przy owym śmiertelnym drzewie" (Apuleius, Metamorphoses VIII 22, ed. J.A. Hanson: Apuleius, Metamorphoses, vol. 2: Books VII-XI, Loeb Classical Library 453 (= LCL), Cambridge Mass. - London 2001, 100).

${ }^{13} \mathrm{~Np}$. deliciae, dzieci niewolnicze obdarzane szczególnymi względami przez właścicieli, ale jeszcze częściej wykorzystywane seksualnie, por. H. Sigismund Nielsen, Delicia in Roman Literature and in the Urban Inscription, „Analecta Romana Instituti Danici” 19 (1990) 79 i 88; B. Rawson, Children and Childhood in Roman Italy, Oxford 2009, 90 i 261-263; Ch. Laes, Children in the Roman Empire, Cambridge 2011, 223-230. Życie ,rodzinne” niewolników: B. Rawson, Children in the Roman Familia, w: The Family in Ancient Rome, ed. B. Rawson, London 1992, 170-200; P. Weaver, Reconstructing Lower - Class Roman Families, w: Childhood, Class and Kin in the Roman World, ed. S. Dixon, London - New York 2001, 101-114; Schumacher, Niewolnictwo antyczne, s. 227-234. 
wśród familia rustica. W tych poczynaniach powinna być bardzo użyteczna jego partnerka, villica. Wszystkie te zasady naruszył jednak zarządca z noweli Apulejusza ${ }^{14}$.

Kolejna nowela dotyczy już ludzi wolnych, majętnych, pochodzących z warstwy średniej lub arystokracji prowincjonalnej. W skrócie historia wygląda następująco: mąż wyjeżdżając nakazał ciężarnej żonie zabicie córki, o ile taka się urodzi ${ }^{15}$. Matka rzeczywiście rodzi dziewczynkę, ale bez wiedzy męża zabezpiecza ją, powierzając w opiekę rodzinie z sąsiedztwa. Po latach dziewczyna osiąga dojrzałość do małżeństwa i staje się pięknością. Matka, chcąc zapewnić przyszłość córce, a zarazem ustrzec przed ewentualnym romansem syna z sąsiadką, wyjawia mu prawdę. Brat postanawia pomóc młodszej, niespodziewanie odzyskanej siostrze, poprzez przyjęcie jej pod swój dach, jako sieroty wymagającej wsparcia, wyznaczenie posagu i zaaranżowanie małżeństwa ze swym przyjacielem. Nie informuje jednak o prawdziwych powodach tych działań swej żony, która - niebezpodstawnie w takiej sytuacji - podejrzewa romans. Były po temu powody, skoro matka także chciała zabezpieczyć córkę przed ewentualnymi zalotami syna.

Podstępem i okrutnie morduje „rywalkę”, a objawy rozpaczy męża bierze za żal po utracie kochanki. Truje więc także jego, a przy okazji córeczkę (parvola filia, infantula), aby odziedziczyć majątek męża. „Po drodze” giną: dostarczyciel trucizny i jego żona, która jednak przed śmiercią ujawnia zleceniodawczynię otrucia. Ta zostaje skazana na publiczne zgwałcenie przez osła w ramach odtwarzania, w czasie przedstawienia teatralnego, sytuacji mitologicznej, a później na rozszarpanie przez dzikie zwierzęta ${ }^{16}$.

${ }^{14} \mathrm{Na}$ temat ideału zob.: Cato Marcus Porcius, De re rustica 5, 1-6; 142; Columella, De re rustica I 8, 1-14. Na temat świata powieści antycznych zob.: Space in the Ancient Novel, ed. M. Paschalis - S. Frangoulidis, Ancient Narrative. Supplementum 1, Groningen 2002.

${ }^{15}$ Por. Apuleius, Metamorphoses X 23-35. Jest to drastyczna, ostra sugestia, aby potępić męża, gdyż mowa właśnie o zabiciu, a nie porzuceniu dziecka: ,[...] ut, si sexus sequiris edidisset fetum, protinus quod esset editum necaretur" tamże X 23, LCL 453, 258. O problemie porzucania/zabijania nowonarodzonych zob. np. J.P. Néraudau, Etre enfant à Rome, Paris 1984, 179-202; T. Wiedemann, Adults and Children in the Roman Empire, London 1989, 36-39 i passim; M. Corbier, Child Exposure and Abandonment, w: Childood, Class and Kin in the Roman World, ed. S. Dixon, London - New York 2001, 52-73; J. Evans Grubbs, Women and the Law in the Roman Empire, London - New York 2002, 267-269; Rawson, Children and Childhood, s. 117-119; J. Evans Grubbs, Hidden in Plain Sight. Expositi in the Community, w: Children, Memory \& Family Identity in Roman Culture, ed. V. Dasen - T. Späth, Oxford 2010, 293-310. Na temat wprowadzenia w pozycję matki w rodzinie zob.: S. Dixon, The Roman Mother, London - Sydney 1988.

${ }^{16}$ W zakończeniu noweli o trucicielce (Apuleius, Metamorphoses X 29-34) Madaureńczyk umieścił długi opisu widowiska mitologicznego, dotyczącego sądu Parysa, w którym to skazana miała zostać zgwałcona przez osła (Lucjusza) symbolizującego nieopanowaną żądzę. W opis Apulejusz włączył dygresję o niesprawiedliwych sędziach. Być może chodziło między innymi o wskazówkę dla czytelnika, że nie tylko kobieta była winna tragedii rodzinnej, jak mógł założyć powierzchowny czytelnik. 
Pozornie wszystko wskazuje na to, że Apulejusz widzi winowajczynię w żonie brata, morderczyni dziewczyny ocalonej od porzucenia. Aranżacja fabuły jest jednak taka, że prawdziwymi winowajcami czyni ojca, który poleca zabić dziewczynkę, mimo dobrej sytuacji społecznej i majątkowej oraz brata, który nie wyjaśnił sprawy swej żonie, a może też niewystarczająco dbał o uczucia w stosunku do niej. Wina w tym przypadku nie jest zresztą aż tak jednoznaczna: matka mogła po pewnym czasie przyznać się do uratowania córki, a żona brata była zbyt zazdrosna i podejrzliwa w stosunku do męża. Członkowie tej rodziny żyli obok siebie, nie komunikowali się, stąd dramatyzm tragedii, jednak z położeniem przez Apulejusza akcentu na winę mężczyzn. Tym samym skrytykowana została patriarchalna postawa władczego męża, który nie rozmawia z żoną, ale wydaje rozkazy. Pozornie silny, napotyka - zgodnie z tradycją komedii greckiej i plautowskiej - na bierny opór kobiet, prowadzący, jak to u Apulejusza, nawet do zbrodni ${ }^{17}$. To najwyraźniej, w ujęciu Madaureńczyka, nie są już czasy, kiedy można było opierać się na dyktacie siły w relacjach rodzinnych, a próby realizacji takiej filozofii życiowej stanowiły dowód prymitywizmu mężczyzn.

Podobnie było w rodzinie oficera (praepositus) dowodzącego „tysiącem żołnierzy". Wdowiec ten w dojrzałym wieku (miał dorosłego, ale jeszcze nie żonatego syna, o wyróżniających się zdolnościach i wysokiej moralności) ożenił się $\mathrm{z}$ o wiele młodszą kobietą, $\mathrm{z}$ którą $\mathrm{w}$ momencie rozpoczęcia narracji miał dwunastoletniego syna. Wybór takiego bohatera mógł być podyktowany chęcią podkreślenia, że bogactwo i wysoka pozycja w społeczności lokalnej (być może był ekwitą i zajmował się sprawami ekonomicznymi armii) nie gwarantują automatycznie szczęścia rodzinnego. W dodatku sugeruje, że oficer był wiecznie zajęty, gdyż miał poważne zadania poza domem ${ }^{18}$.

Dzięki sile charakteru i urodzie żona przejęła rządy w domu. W dodatku macocha zakochała się w pasierbie, ale ten po wyznaniu przez nią niegodnych uczuć, nie powiadomił ojca, a tylko odwlekał na różne sposoby nawiązanie romansu ${ }^{19}$. Zawiedziona kobieta postanowiła otruć niedoszłego kochanka, a gdy przez pomyłkę rzekomą truciznę wypił jej rodzony syn, oskarżyła pa-

${ }^{17}$ Apulejusz a Plaut: Finkelpearl, Metamorphosis of Language in Apuleius, s. 11 i passim; L. Passetti, Plauto e Apuleio, Bologna 2007; A. Kirchenko, Writing Like a Clown: Apuleius 'Metafiction and Plautus' Metatheater, „Göttinger Forum für Altertumswissenschaft” 10 (2007) 259-271 i podana tam literatura.

${ }^{18}$ Por. Apuleius, Metamorphoses X 1-12. Praepositus: oficer do różnych zadań, raczej o charakterze techniczno-ekonomicznym, o różnym znaczeniu, co najmniej średniej rangi, ekwita, zob. P. Southern, The Roman Army: A Social and Institutional History, Oxford 2007, 124-140. Miłość, seks w powieściach antycznych: D. Konstan, Sexual Symmetry. Love in the Ancient Novel and Related Genres, Princeton 1994 (odnośnie do Apulejusza s. 125-139, zwłaszcza porównania z mitem o Fedrze s. 130-133).

${ }^{19}$ Opinie (na ogół negatywne) o macochach w źródłach starożytnych: P.A. Watson, Ancient Stepmother. Myth, Misoginy, and Reality, Leiden - New York - Köln 1995; u Apulejusza (analogie $\mathrm{z}$ mitem o Fedrze): Finkelpearl, Metamorphosis of Language in Apuleius, s. 149-183. 
sierba o napastowanie seksualne i o uśmiercenie przyrodniego brata. Na chwilę przed skazaniem na śmierć starszego syna (ojciec uwierzył bez namysłu macosze) lekarz, który sprzedał „truciznę” oświadczył, że był to tylko silny napój nasenny i chłopiec pochowany już w grobowcu został wybudzony ze śpiączki przypominającej śmierć. Historia kończy się oświadczeniem ojca, iż jest szczęśliwy, że jednego dnia odzyskał dwóch synów, oraz informacją, że macochę skazano na wygnanie, a niewolnika, który jej pomagał ukrzyżowano.

To dziwne zakończenie, dziwne choćby w świetle kary dla kobiety z poprzedniej nowelki, wskazuje zarazem na prawdziwego winowajcę. Nie jest nim żona, której mąż, przecież dowódca wojskowy dosyć wysokiego szczebla, oddał całkowicie zarząd domu i nie dostrzegał, iż jest ona osamotniona i coraz bardziej zainteresowana jego synem.

Cechował go brak wiary w prawość syna z pierwszego małżeństwa, a więc i słaby z nim kontakt, gdyż młodzieniec, mając kłopoty szukał rady nie u swego ojca, ale u starego wychowawcy. Oficer uległ pokusie przedłużania młodości poprzez małżeństwo z o wiele młodszą kobietą, na którą scedował sprawy domowe. Brak zainteresowania relacjami rodzinnymi, w ujęciu Apulejusza, czyni go rzeczywistym winowajcą, stąd tak mała kara dla macochy. Także pasierb nie zachował się ,po męsku” i nie przeciął jednoznacznie niewczesnych amorów macochy, zwodził, doprowadzając do furii swą bezczynnością tak energiczną kobietę, dotychczas realizującą wszelkie swoje plany. Tylko ona, choć w zbrodniczy sposób kieruje akcją, dąży do celu, gdy mężczyźni poddają się biegowi wypadków, wyczekują, wybierają najprostsze rozwiązania. Zakończenie historii to wyraźna kpina z wojaka, który nic nie zrozumiał z tragedii, która nieomal zniszczyła mu rodzinę, a którą sam zresztą wywołał, choć z biernym udziałem starszego syna.

Kolejny przykład niejednoznacznie rozłożonych akcentów, co do winy za rozpad więzi rodzinnych, jest historia młodej żony dekuriona Barbarusa, o imieniu Arete ${ }^{20}$. Małżonka o równej (może wyższej, chociaż jest biedniejsza) mężowi pozycji społecznej, bardziej od niego wykształcona (opozycja imion: Barbarus i Arete), traktowana była przez niego jak bezwolna własność. $\mathrm{W}$ dodatku, będąc o nią chorobliwie zazdrosnym, zawierzył pilnowanie jej pod swą nieobecność niewolnikowi, co musiało poniżyć żonę. Ta odpowiedziała zdradą, ale Apulejusz zakomponował ją specyficznie. Arete, słynąca do tej pory z cnotliwości, miała oddać się kochankowi za pieniądze (choć za dużą stawkę 20 aureusów), a niewolnik otrzymał za milczenie i pomoc nieomal for-

${ }^{20}$ Por. Apuleius, Metamorphoses IX 17-21. Barbarus - imię zapożyczone z greki, z grupy oznaczającej obcych, dziwnych, o wydźwięku negatywnym, częste w Afryce rzymskiej, zob. I. Kajanto, The Latin Cognomina, Helsinki 1965, 18, 81 i 312. Na temat arete jako cnoty, doskonałości zob.: H.I. Marrou, Historia wychowania w starożytności, tłum. S. Łoś, Warszawa 1969, 31-148. Na temat kobiet wykształconych, ale tylko spośród elity zob.: E.A. Hemelrijk, Matrona docta. Educated Women in the Roman élite from Cornelia tu Julia Domna, London - New York 1999. 
tunę dla niego, bo 10 aureusów ${ }^{21}$. Zdrada nie wyszła na jaw, a Barbarus (zwany także Skorpionem, więc podstępny, przebiegły, bezwzględny i zabójczy) został ośmieszony ${ }^{22}$. Przypowiastka mieszcząca się w kanonie prostych, żeby nie powiedzieć trywialnych „kupletów”, zawiera pozornie ni mniej, ni więcej, tylko pochwałę zdrady za pieniądze, niewiele różniącej się (może w ogóle?) od prostytucji, i to w wykonaniu wolnej, wykształconej kobiety ${ }^{23}$.

Zachowanie Arete ledwo mieści się w zakresie dopuszczalnej zemsty za znieważenie i ośmieszenie przez męża, każącego dosłownie przywiązywać do siebie (niewolnik robił tak pod nieobecność męża) wolną kobietę. Być może Barbarus - Skorpion został w ten sposób ukarany także za skąpstwo, chciwość, a żona zaczęła drogą płatnej zdrady zbierać fundusze na życie po rozwodzie, co Apulejusz akceptuje, a nie samą zdradę tylko z zemsty czy z nudów.

W jego ujęciu brutalna siła i majątek, a nawet stanowisko w społeczeństwie (należał do zarządu miasta) nic nie znaczą wobec praw i racji wykształconej, pewnej siebie, pięknej kobiety. Należało o nią zadbać, a nie traktować jak własność. Mamy tu analogię do Plauta i Terencjusza, zresztą także innych moralistów rzymskich przestrzegających przed układaniem relacji małżeńskich z pozycji siły ekonomicznej, w tym przypadku męża ${ }^{24}$.

O wiele brutalniejsza jest opowieść, pozornie traktująca o skutkach zdrad żony młynarza ${ }^{25}$. Kobieta, chyba najostrzej scharakteryzowana w powieści poprzez kilkanaście negatywnych epitetów, w dodatku macocha dla córki męża z pierwszego małżeństwa, zdradza bez przerwy męża, który niczego nie jest świadomy ${ }^{26}$.

W momencie rozpoczęcia akcji opowiada swej połowicy o przykrościach sąsiada, folusznika, którego zdradza żona. Doradził mu, aby rozstali się na pewien czas, co być może pozwoli na późniejsze pogodzenie. W tym samym czasie kochanek ukrywa się przed nim w jego domu. Gdy młynarz odkrywa zdradę własnej żony, „używa” złapanego młodzieńca także jako kochanka,

${ }^{21}$ Wartość aureusów w świetle płac i cen: S. Mrozek, Prix et rémunération dans l'Occident Romain, Gdańsk 1975, 10-126 (np. gladiator w Italii II w. -4000 sesterców = 40 aureusów; niewolnica $2500=25$ aureusów; koń $1600=16$ aureusów).

${ }^{22}$ Symbolika skorpiona: D. Forstner, Świat symboliki chrześcijańskiej, thum. zbiorowe, Warszawa 1990, 300-301.

${ }^{23}$ Na temat prostytucji w Rzymie zob. np.: T.A.J. McGinn, Prostitution, Sexuality, and the Law in Ancient Rome, Oxford 1998; B.E. Stumpp, Prostitution in der römischen Antike, Berlin 1998.

${ }^{24}$ Jednak Katon wybrał żonę o wysokiej pozycji społecznej, lecz biedniejszą od niego, por. J. Jundziłł, Wzorce i modele wychowania w rodzinie rzymskiej okresu III w. p.n.e. - III w. n.e., Bydgoszcz 2001, 20-27.

${ }^{25}$ Por. Apuleius, Metamorphoses IX 11-13; 22-31.

${ }^{26}$ Por. tamże IX 14. Na temat cudzołóstwa zob. Treggiari, Roman Mariage, s. 262-322 i passim. Część badaczy uważa, że za tak ostrą charakterystyką wad kryje się chrześcijanka, np. umieszczenie tego fragmentu w : Pierwsi świadkowie, opr. M. Starowieyski, OŻ 8, Kraków 1988, 403-405, w rozdziale XI: „Pogarda, plotka, oszczerstwo - pisarze pogańscy II wieku o chrześcijanach; P.G. Walsh, The Roman Novel, Bristol 1995, 186-189; V.L. Schmidt, Reaktionen auf das Christentum in den Metamorphosen des Apuleius, VigCh 51 (1997) 51-71. 
a dopiero później wyrzuca kobietę z domu. Żona nasyła jednak na niego czarownicę, która ma spowodować powrót uczuć męża, a gdyby to się nie udało, ma doprowadzić go do samobójstwa, co też się staje ${ }^{27}$. Nowelę kończy informacja, że córka z pierwszego małżeństwa, wydana za mąż w sąsiedztwie, sprzedaje majątek i wraca do siebie, czyli to jej ojciec zapisał wszystko, a nie żonie (może jednak chodziło o część spadku, przeznaczoną dla dziewczyny). Nic natomiast Madaureńczyk nie wspomina o karze dla młynarki i jej dalszym losie.

O młynarzu wiemy od autora tyle, że „był ostatecznie człekiem dobrym i całkiem porządnym" 28 , ale młyn, który prowadził, działający dzięki straszliwemu wyzyskowi niewolników i zwierząt obracających żarna, przedstawiony jest jako piekło na ziemi ${ }^{29}$. Ta dobroć musiała więc być nieco powierzchowna, a obciążała go chciwość, skoro tak bezwzględnie traktował pracowników młyna oraz zwierzęta. Być może mamy tu także przewrotną aluzję do ideału republikańskiego arystokraty, senatora, mającego być właśnie vir bonus, który uczciwą pracą, wysiłkiem buduje majątek i służy społeczności, co nieco odbiega od wizerunku młynarza. Jednak czasami ci „,wzorowi” arystokraci łupili społeczeństwo i nieraz, przez chciwość i nieposkromione ambicje, doprowadzali państwo na skraj upadku. Wtedy analogia z młynarzem jest jeszcze bardziej przejrzysta ${ }^{30}$.

Brak kary na zdradliwą kobietę wskazuje na intencję Apulejusza, by widzieć także winę męża za rozpad w rodzinie. Nie miał z nową, młodszą od siebie (?) żoną dzieci, wyposażył tylko (?) córkę, a także najwyraźniej nie zaspokajał wygórowanych potrzeb seksualnych żony, a przy tym nie stronił od homoseksualizmu ${ }^{31}$. Największą jednak winą było nierozpoznanie wad żony i zbyt duża - jak chce Apulejusz - tolerancja w stosunkach małżeńskich, co może oznaczać chłód uczuciowy i niechęć do angażowania się w małżeństwo.

${ }^{27}$ Opis działań żony poprzez sprowadzenie wiedźmy wyraża skłonność Apulejusza do zadziwiania czytelnika niecodziennymi zjawiskami i sytuacjami (curiositas), którym nadaje neoplatońską wymowę, por. J. DeFilippo, Curiositas and the Platonism of Apuleius' Golden Ass, w: Oxford Readings in the Roman Novel, s. 269-289; na temat czarownic zob. Frangoulidis, Withes, Isis and Narrative, passim.

${ }^{28}$ Apuleius, Metamorphoses IX 14, LCL 453, 150: „Pistor ille qui me pretio suum fecerat, bonus aliquin vir et apprime modestus [...]”, thum. Jędrkiewicz, s. 189.

${ }^{29}$ Por. tamże IX 11-13. Być może chodzi o krytykę chciwości młynarza, który zamiast zainwestować w młyn wodny wolał wykorzystywać tanich (starych?) niewolników i zajeżdżane na śmierć zwierzęta, i to pod ziemią, a nie jak np. w Ostii czy Pompejach, na powierzchni. Na temat młynów rzymskich zob.: Cato Marcus Porcius, De re rustica 10; Ovidius, Fasti VI 318; Mt 18, 6; por. L. Moritz, Grain Mills and Flour in Classical Antiquity, Oxford 1958; A.T. Hodge, A Roman Factory, „Scientific American” vol. 263, issue 5 (November 1990) 106-111.

${ }^{30} \mathrm{Na}$ temat vir bonus zob. T. Sinko, De romanorum viro bono, „Rozprawy Polskiej Akademii Umiejętności. Wydział Filologiczny" 36 (1904) 251-300. Metamorfozy zbudowane są na kanwie przemiany młodzieńca $\mathrm{w}$ osła $\mathrm{i} \mathrm{w}$ wielu miejscach powieści odczuwa się empatię jej autora $\mathrm{w}$ stosunku do zwierząt.

${ }^{31}$ Por. np. J.P. Hallet - M.B. Skiner, Roman Sexualities, New Jersey 1998, 6-22 i passim. 
Być może dlatego historia kończy się samobójstwem męża, a młynarki nie spotyka kara.

Zestaw historii dotyczących winy mężczyzn, przede wszystkim na polu stosunków małżeńskich, kończę historią małżeństwa Charyty i Tlepolemusa, wplecioną w najważniejszą w tym względzie w Metamorfozach, przynajmniej z racji objętości, opowieść o Kupidzie i Psyche ${ }^{32}$. Pozornie klęska Charyty nie została przez nią zawiniona. Apulejusz chce jednak najwyraźniej dać do zrozumienia, że w „idealnym” małżeństwie - stworzonym przez młodych, którzy znali się od dzieciństwa i od dawna kochali, co akceptowali rodzice dziewczyny, u których to mieszkał jako krewny także Tlepolemus - są istotne rysy. Możliwość małżeństwa z Trazyllusem, konkurentem Tlepolemusa, nie została zaakceptowana przez rodziców dziewczyny z racji ciemnych plam na jego życiorysie, co jednak nie przeszkadzało Tlepolemusowi traktować go jako przyjaciela.

Młoda żona dbała wraz z rodzicami o dobro męża (mieszkają w majątku rodziców tak, jak przed ślubem). Apulejusz wspomina, że żona nie pozwalała młodemu małżonkowi nawet na polowania na nieco groźniejszą zwierzynę, aby przypadkiem coś mu się nie stało, a wcześniej charakteryzował go jako idealnego młodzieńca, a więc polowanie, męskie sporty powinny były stanowić treść jego życia.

Wyrwawszy się w końcu spod płaszcza nadopiekuńczej żony ginie w trakcie wspólnego polowania, zamordowany przez „przyjaciela”, który zrzuca winę na nadzwyczaj wielkiego dzika. Żona doznawszy wizji, w której mąż zdradza jej, w jaki sposób zginął, podstępnie zwabia do sypialni Trazyllusa, obiecując, że mu ulegnie, ale odurzonego napojem nasennym oślepia, a sama popełnia samobójstwo. Trazyllus, dręczony wyrzutami sumienia, każe się zamurować żywcem w ich grobowcu ${ }^{33}$.

Czym zawinił więc w koncepcji Apulejusza Tlepolemus, a czym Charyta? Tak, jak młynarz, młody mąż nie zdawał sobie sprawy, co się wokół niego dzieje, nie był czujny, bo wszystko otrzymał bez wysiłku i zasług. Był tylko najlepiej prezentującym się młodzieńcem w okolicy, kochanym przez żonę za zewnętrzne walory. Pozwolił zniewolić się żonie, bezmyślnie dopuszczał, jak i Charyta, do rodziny człowieka odrzuconego przez teściów, jako kandy-

${ }^{32}$ Por. Apuleius, Metamorphoses IV 26-27; VI 25-32; VII 1-14; VIII 1-14. Carite, od imienia Charitas (Caritas), cnota, miłość, miłosierdzie z grupy imion pochodzących od cech abstrakcyjnych, rzadkie, por. Kajanto, The Latin Cognomina, s. 285 i 364; Tlepolemus: wytrzymały wojownik, por. J.A. Hanson, LCL 453, 26, nota 2.

${ }^{33}$ Samobójstwo Charyty w grobowcu męża i zamurowanie się w nim Trazyllusa to ironiczne nawiązanie do opowieści Petroniusza (Satiricon 111-112) o wdowie z Efezu, która rozpacza w grobowcu męża nad jego zwłokami. W końcu jednak pociesza ją strażnik zwłok ukrzyżowanego obok przestępcy. Wykorzystując jego amory rodzina przestępcy wykrada zwłoki ukrzyżowanego, by zapewnić mu chociaż pogrzeb, ale strażnikowi za zaniedbanie obowiązków grozi surowa kara. Zakochana w nim wdowa poświęca zwłoki męża, które umieszczają na krzyżu, a tym samym kochanek unika kary. 
data na małżonka. Chciałoby się powiedzieć, że był piękny i dzielny (uwolnił z rąk bandytów narzeczoną), ale głupi. Podobnie zachowała się zresztą jego żona, traktująca małżeństwo jako przedłużenie bezproblemowej egzystencji w rodzinie pierwotnej, pod okiem i na koszt rodziców. Ironiczne nawiązanie w końcu noweli do opowieści o wdowie z Efezu z Satyryk Petroniusza podważa heroiczność samobójczego gestu Charyty i wskazuje, że wszyscy bohaterowie tej tragedii uczynili z niej farsę przez nieodpowiedzialne poczynania, choć wina mężczyzn była większa, niż młodej żony.

Choć nowela o Psyche należy do najobszerniejszych i być może najważniejszych dla Apulejusza, z racji zawartych tam aluzji do filozofii Platona, to dla analizowanego tu zagadnienia jest mniej nośna ${ }^{34}$. Zakochany w Psyche, najpiękniejszej z ziemianek, syn Wenus umieszcza ją w luksusowym pałacu z „pełną obsługą”, ale sam nie chce się jej ukazać i powiedzieć, kim naprawdę jest. Pobudzona ciekawość osamotnionej kobiety doprowadza do próby odkrycia, jak wygląda jej kochanek, co pomoże także ustalić jego tożsamość. Amor karze ją za to porzuceniem i odejściem do matki na Olimp. Kara spada na przyszłą matkę jego dziecka za brak ślepego posłuszeństwa zaleceniom mężczyzny, bez choćby próby wytłumaczenia, dlaczego są takie, a nie inne.

Mimo tak egoistycznego podejścia mężczyzny do relacji z kobietą, ona walczy z przeciwnościami losu i bogami, aby uratować związek i zapewnić dziecku ojca oraz pełną rodzinę. Choć w tej historii Apulejusz krytykuje raczej Wenus za zaborczość wobec syna i chęć zniszczenia rywalki do jego uczuć, charakterystyka Kupida nie jest mu zbyt przychylna. Traktuje instrumentalnie kochankę i doprowadza nieomal do jej śmierci w trakcie poszukiwań drogi do niego. Nie interesuje go, co może odczuwać, gdy ją porzucił. W tej historii kary nie ma, a dopiero interwencja Jowisza, który opowiedział się po stronie Psyche, kończy sprawę pomyślnie, ślubem i urodzeniem córki.

Być może łącznikiem między opowieścią o Psyche i małżeństwie Charyty jest niedojrzałość do głębokiego, poważnego związku z kochaną, powierzchowne potraktowanie kobiety, która przecież, jak Psyche, będzie matką ich dziecka. Nieświadomość zagrożeń, jakie niesie nawet z pozoru bezproblemowe życie, mogące przecież w każdej chwili się załamać, jest winą Kupida i Tlepolemusa, gdyż nie zabezpieczają oni bliskich przed mogącymi w każdej chwili wystąpić kryzysami.

$\mathrm{Na}$ koniec odmienna historia, ostatnia $\mathrm{z}$ wybranych przeze mnie opowieści. Dotyczy ona nie relacji między małżonkami, a stosunków między oj-

${ }^{34} \mathrm{Na}$ temat Psyche zob.: Apuleius, Metamorphoses IV 28-35; V 1-35; VI 1-24; VIII 14; zob. Konstan, Sexual Symmetry, s. 125-138; D. Rollo, From Apuleiu's Psyche to Chrétien's Erec and Enide, w: The Search for Ancient Novel, ed. J. Tatum, Baltimore - London 1994, 347-369; Sandy, The Greek World of Apuleius, s. 176-255. Cupido (żądza, miłość), Psyche (dusza) to aluzje do filozofii Platona, por. Sandy, The Greek World of Apuleius, s. 255. 
cem i dorosłymi synami, choć odniesienia do takich relacji występowały już w omawianych wcześniej nowelach, ale pobocznie ${ }^{35}$.

Stary ojciec był dumny ze swoich synów, z których dwaj byli już dojrzali, ale nie żonaci, trzeci - na progu dojrzałości. Mieszkali razem z wdowcem, należąc przynajmniej do klasy średniej, gdyż ojciec był właścicielem ziemskim. Synowie przyjaźnili się z sąsiadem, mającym niewielki majątek ziemski, na który, jako dopełnienie swoich wielkich dóbr, miał ochotę latyfundysta. Kłótnia z nim, otoczonym ciżbą członków familii, zakończyła się śmiercią latyfundysty oraz trzech braci, a zdarzenie poprzedziły znaki wróżebne (prodigia), skonstruowane przez Apulejusza z wielką przesadą, ale i humorem ${ }^{36}$. Na wieść o śmierci synów ojciec popełnił samobójstwo na oczach biesiadników, czekających na powrót synów.

Kluczem do próby zrozumienia intencji stworzenia takiej fabuły, luźno związanej z tokiem dotychczasowej akcji powieści, jest opis śmierci braci, których Apulejusz przedstawia jako nie tylko wiernych ojcu, ale i silnie ze sobą związanych ${ }^{37}$. Najmłodszy zginął potknąwszy się o kamień, rozszarpany przez wielkie psy myśliwskie, najstarszy od rzutu oszczepem, który przebił go w taki sposób, że zwłoki utrzymywały się w pozycji stojącej, tworząc obraz „żywego" trupa. Średni brat, uśmierciwszy z zemsty młodego, pazernego arystokratę, popełnił samobójstwo nie chcą wpaść w ręce członków familii wroga (z obawy tortur?), ale Apulejusz właściwie nie wyjaśnił, dlaczego.

Opowieść odczytuję jako symboliczne ukazanie patologii $\mathrm{w}$ rodzinie wdowca. Synów zabiła przesadna, długotrwała wierność ojcu (kamień, o który potknął się najmłodszy, psy jako symbole wierności), który egoistycznie nie zezwolił im na usamodzielnienie się i odejście z domu, w którym nie chciał pozostać sam. Świadczy o tym natychmiastowe samobójstwo na wieść o śmierci synów, egoistycznie poddał się on rozpaczy, nie zadbawszy wcześniej nawet o należyty pochówek synów.

Wierność ojcu symbolizują psy, które rozszarpały jednego z braci, tak jak zbytnia uległość, wierność ojcu doprowadziła do „śmierci” cywilnej braci (najstarszy - „żywy trup”, samobójstwo średniego), którzy nie mogli założyć rodzin i tworzyć nowej siatki relacji społecznych. Egoizm ojca był więc równie „śmiertelny”, jak chciwość latyfundysty, narażającego się dla zdobycia siłą kolejnego skrawka ziemi, dla niego mało ważnego, a dla właściciela będącego ojcowizną.

${ }^{35}$ Por. Apuleius, Metamorphoses IX 33-39.

${ }^{36}$ Por. tamże IX 34: m.in. krew buchająca spod stołu w jadalni; wrzące wino; pies pasterski zagryziony przez barana.

${ }^{37} \mathrm{O}$ uczuciach między braćmi: C.J. Bannon, The brothers of Romulus. Praternal pietas in Roman Law, Literature, and Society, Princeton 1997. Na temat ojca zob.: P. Garnsey, Sons, Slaves and Christians, w: The Roman Family in Italy. Status, Sentiment, Space, ed. B. Rawson - P. Weaver, Oxford 1997, 101-122; Jundziłł, Wzorce i modele wychowania $w$ rodzinie rzymskiej, s. 136-141, 174-182 i 247-257. 
W Metamorfozach odpowiedzialność za patologie życia rodzinnego spada często na mężczyznę. Czy oznacza to dowartościowanie kobiet? Nie jest to takie oczywiste. Skierowanie oskarżeń na mężczyznę można interpretować jako uznanie jego przewagi, kierowniczej roli opartej na większych możliwościach intelektualnych i jej marnowanie przez bezmyślność i brak komunikacji z członkami rodziny. W dodatku mężczyźni prowokowani są przez kobiety i poddani namiętnościom, którym nie potrafią się przeciwstawić. Sądzę jednak, że w powieści Apulejusza nie chodzi głównie o to, a o propozycję oparcia stosunków rodzinnych na zrozumieniu i porozumieniu między członkami rodziny, co można osiągnąć jedynie przy pełnej komunikacji interpersonalnej. Jej brak prowadzi do patologii. Wydaje się, że taki model relacji w swoim małżeństwie przekazał w Apologii.

Warto także zastanowić się, jaki wzorzec mężczyzny stworzył Apulejusz w Metamorfozach ${ }^{38}$. Sądząc z wymowy Apologii wygłoszonej w czasie rozprawy, dotyczącej oskarżenia o stosowanie magii dla pozyskania względów bogatej wdowy, miał siebie za naukowca, filozofa, nie tylko etyka, ale i filozofa przyrody, badacza wszystkiego, co stanowi wyzwanie intelektualne, i taki wzór, dostosowany do realiów życia różnych warstw społecznych propagował.

Uważam, że zarówno dzieła filozoficzne, jak i Metamorfozy powstały po procesie i po wyjeździe do Kartaginy oraz osiągnięciu stabilizacji życiowej. Trauma wywołana posądzeniami o polowanie na majątek wdowy, oskarżenia pasierbów o interesowność i pozbawienie ich należytego spadku, odreagował pisząc satyrę na małostkowość ludzi i powierzchowne podejście do życia. W taką postawę wpisuje się jego obraz mężczyzny i przypuszczalny ideał.

Powieść Apulejusza odzwierciedla sytuację społeczno-prawno-obyczajową, w której mężczyzna z pewnością miał formalną przewagę nad kobietą. Nie były to już jednak czasy siermiężnych stosunków rodzinnych w epoce pierwotnego Rzymu, prostych relacji ekonomicznych i obyczajowych. Kobiety zyskały szereg możliwości obchodzenia formalnych zakazów i było na to przyzwolenie społeczne, o ile oczywiście kobieta osiągnęła co najmniej średni status społeczny i ekonomiczny. Sądzę zresztą, że w warstwach niższych ta chwiejna równowaga prowadziła do coraz większej równości kobiet i mężczyzn. Świadczy o tym spora ilość danych o prowadzeniu samodzielnej działalności ekonomicznej przez kobiety i istotny ich współudział w poczynaniach mężczyzn, czego dobrym przykładem jest żona Trymalchiona oraz dowartościowanie w napisach nagrobkowych żon i matek przez wyzwoleńców i niewolników ${ }^{39}$.

${ }^{38}$ Wzorce męskości w okresie starożytności klasycznej: When Men Were Men. Masculinity, Power, and Identity in Classical Antiquity, ed. L. Foxhall - J. Salmon, London - New York 1998.

${ }^{39}$ Por. N.B. Kampen, Image and Status Roman Working Women in Ostia, Berlin 1981; J.K. Evans, War, Women and Children in Ancient Rome, London - New York 1991, 7-165 i 210-218. 
Mężczyzna w społeczeństwie rzymskim II w., przynajmniej na Zachodzie, musiał wykazać się czymś więcej, niż tylko powoływaniem się na przynależną mu formalną przewagę. Zacięcie satyryczne czy wręcz zgorzknienie miałkością otoczenia spowodowało, że w powieści Apulejusz tworzył na ogół negatywne wzorce zachowań męskich, choć mocno kamuflował krytykę ich postępowania poprzez pozorne kierowanie oskarżeń na kobiety, być może nie chcąc zrażać co bardziej konserwatywnych czytelników.

Jaki więc jest ten pozytywny model mężczyzny idealnego? Wydaje mi się, że takiego ideału nie warto jednak u Apulejusza szukać wyłącznie w sferze rodzinnej i codziennego bytowania, a bardziej w sferze duchowej doskonałości, a właściwie na drodze dochodzenia do niej i to nie w tak prosty sposób, jakby sugerowała ostatnia księga Metamorfoz - oddania się rytualnemu kultowi Izydy ${ }^{40}$.

Jednak i w życiu rodzinnym można było budować fragmenty pozytywnego rozwoju duchowości i doskonalenia się poprzez nieuleganie pozornym wartościom. Ułudą było piękno ciała i majątek, powodzenie ekonomiczne i kariera. Co z tego, że Barbarus był lokalnym arystokratą, ale nie potrafił zrozumieć potrzeb swej żony, która ośmieszyła go przed całym miastem? Niewolnik, bliski wyzwolenia i awansu społeczno-ekonomicznego, chce za wszelką cenę przyśpieszyć ten proces, lekceważąc los żony i nowonarodzonego dziecka.

Nie cieszy się uznaniem Apulejusza ułatwianie sobie życia prostackim uleganiem nie do końca przemyślanym zachciankom. Starzejący się oficer nie tylko cieszy się młodą żoną, ale i oddaje jej zarząd nad domem, gdzie żyje dojrzewający syn, który powinien przejąć takie obowiązki. Inny ojciec dla przyjemności i z egoistycznej obawy przed samotnością wdowca trzyma przy sobie synów, nie dając im szans na samodzielne życie.

Nie uzyskuje aprobaty bezproblemowe życie, a właściwie unikanie podejmowania odpowiedzialności i przewidywania skutków własnych decyzji. Młynarz trwa w związku ze złą, podłą kobietą, jak sugeruje Apulejusz dla „świętego spokoju” spokoju, mąż Charyty godzi się na życie pod skrzydłami żony i jej rodziców, stając się całkowicie ubezwłasnowolnionym bawidamkiem.

Autor Metamorfoz stawia proste, ale nadzwyczaj trudne do całkowitego spełnienia wymogi przed mężczyzną jako mężem i - nieco rzadziej - ojcem.

\footnotetext{
${ }^{40}$ Np. już T. Sinko (Metamorfozy Apulejusza jako romans wychowawczy, „Meander” 8 (1953) z. 4-6, 176-189) i Holzberg (Powieść antyczna, s. 118-120) uznają niby poważny ton księgi XI za kolejny żart z powierzchownego czytelnika, choćby z tej racji, iż wcześniej bezlitośnie kpił z kapłanów oszukujących naiwnych wyznawców. Bardziej zaawansowana i zgodna ze sposobem myślenia Apulejusza jest interpretacja D. Lateinera (Marriage and Return of Spouses in Apuleius' Metamorphoses, „The Classical Journal” 95 (2000) nr 4, 313-332) historii małżeńskich poprzez odczytanie księgi XI, poświęconej Izydzie, jako nawiązania do mitu o niej, jako zworniku życia małżeńskiego i rodzinnego, w którym to ona, a nie Ozyrys, odgrywa pierwszoplanową rolę.
} 
Ma on być odpowiedzialny za swe czyny i decyzje, nie tylko w wymiarze bliskim, teraźniejszym, ale przede wszystkim dalekosiężnym, jak przystało na wykształconego, refleksyjnego człowieka, który rozpoznaje egzystencjalne zagrożenia i prawdziwe, a nie pozorne dobro. Jednym z wymiarów tego dobra jest ład rodzinny, a tym samym społeczny, co jest kontynuacją, a może raczej powrotem do idei sprzężenia zwrotnego między rodziną a społeczeństwem, istniejącego w pierwotnym Rzymie.

Ład osiągany z dobrym rezultatem w życiu państwowym przekłada się na postulat konieczności zapewnienia go i w rodzinie, a nie ulegania chwilowym żądzom i egoistycznym potrzebom. O tym między innymi traktuje największa objętościowo i jedna z ważniejszych ideowo opowieści: nowela o Kupidzie i Psyche, a właściwie wbrew tradycyjnemu tytułowaniu - o Psyche i Kupidzie, gdyż to kobieta pełni w niej ważniejszą rolę niż bożek. To ona wskazuje, co jest ważne w związku: wiara, wierność, odpowiedzialność i determinacja w realizacji celu polegającego na zapewnieniu dobra uczestnikom życia rodzinnego, nawet jeszcze nienarodzonym, a nie namiętność, pożądanie, bogactwo i prestiż najwyższej pozycji społecznej ${ }^{41}$.

Kobieta z poświęceniem walczy o odzyskanie zaufania partnera, które bezmyślnie, utraciła ulegając podszeptom kochających ją, jak sądziła, sióstr. Mężczyzna, poza wyegzekwowaniem konsekwencji popełnienia błędu przez przyszłą matkę ich dziecka, czyli rozstaniem i powrotem na łono matki - bogini, nie robi nic, aby zaakceptować nadludzkie wysiłki Psyche, by go odzyskać. Najwyraźniej tak płytka i bierna rola mężczyzny nie odpowiada Apulejuszowi, który chciał wszystko traktować w kategoriach intelektualnej analizy.

Sądzę, że tak samo postąpił z własnym małżeństwem, zaplanowanym z korzyścią dla niego i przyszłej partnerki. Nie przewidział tylko, że codzienność bytu zawiera zbyt dużą ilość zmiennych, aby wszelkie okoliczności podjętych decyzji dały się przewidzieć, a otoczenie społeczne często nie rządzi się logiką, a bardziej niskimi emocjami, zwłaszcza zawiścią i podłością. Z tego powodu omal nie przegrał, ale w wyniku tego przykrego starcia ideałów z rzeczywistością powstały Metamorfozy. W swej wymowie były, jak sądzę, podobne bardziej zaawansowanym i przemyślanym propozycjom Ojców Kościoła odnośnie do życia rodzinnego.

${ }^{41}$ Aspects of Apuleius' Golden Ass, vol. 2: Cupid and Psyche, ed. M. Zimmerman i inni, Groningen 1998. 


\section{METAMORPHOSIS ATTITUDE TOWARDS MAN. APULEIUS ABOUT MEN \\ RESPONSIBLE FOR PATHOLOGICAL SITUATION IN FAMILY}

(Summary)

In Apuleius novel we have a seeming attack on bad character, bad behaviour of women for example main character is turn in to donkey by the witch. If we carefully analyse his literature that cover a topic of in family relationships, it can be notice thesis that, it is husband fault, by the rash and botched decision, lack of communication, starts conflicts that sometimes lead women to commit crimes. This confirm thesis that also Church Fathers preach about great responsibility of the husbands and fathers for shaping relation in his family.

Key words: Apuleius, Roman novel, husband, father, wife, mother, children, communication.

Słowa kluczowe: Apulejusz, powieść rzymska, mąż, ojciec, żona, matka, dzieci, komunikacja interpersonalna. 